\title{
Correlates of compliance with national comprehensive smoke-free laws
}

\author{
Armando Peruga, ${ }^{1}$ Luminita S Hayes, ${ }^{2}$ Ximena Aguilera, ${ }^{1}$ Vinayak Prasad, ${ }^{2}$ \\ Douglas W Bettcher ${ }^{2}$
}

${ }^{1}$ Center for Epidemiology and Health Policy, Facultad de Medicina, Clínica Alemana Universidad del Desarrollo, Santiago, Chile

2Prevention of

Noncommunicable Diseases, World Health Organisation, Geneva, Switzerland

\section{Correspondence to}

Dr Armando Peruga, Center for Epidemiology and Health Policy, Facultad de Medicina Clínica Alemana Universidad del Desarrollo, Av. Las Condes 12496, Lo Barnechea 7610658, Chile; aperuga@udd.cl

Received 26 June 2017 Revised 31 August 2017 Accepted 2 October 2017

Published Online First

5 December 2017

Check for updates

To cite: Peruga A, Hayes LS, Aguilera $X$, et al. Tob Control 2018:27:608-613

\section{ABSTRACT \\ Objective To explore correlates of high compliance with smoking bans in a cross-sectional data set from the 41 countries with national comprehensive smoke-free laws in 2014 and complete data on compliance and enforcement. Methods Outcome variable: compliance with a national comprehensive smoke-free law in each country was obtained for 2014 from the WHO global report on the global tobacco epidemic. Explanatory variables: legal enforcement requirements, penalties, infrastructure and strategy were obtained through a separate survey of governments. Also, country socioeconomic and demographic characteristics including the level of corruption control were included. Analysis: an initial bivariate analysis determined the significance of each potentially relevant explanatory variable of high compliance. Differences in compliance were tested using the exact logistic regression.}

Results High compliance with the national comprehensive smoke-free law was associated with the involvement of the local jurisdictions in providing training and/or guidance for inspections (OR=10.3, 95\% Cl 1.7 to 117.7) and a perception of high corruption control efforts in the country (OR=7.2,95\% Cl 1.1 to 85.8).

Discussion The results show the importance of the depth of the enforcement infrastructure and effort represented by the degree to which the local government is involved in enforcement. They also show the significance of fighting corruption in the enforcement process, including the attempts of the tobacco industry to undermine the process, to achieve high levels of compliance with the law. The results point out to the need to invest minimal but essential enforcement resources given that national comprehensive smoke-free laws are self-enforcing in many but not all countries and sectors.

\section{INTRODUCTION}

Smoke-free laws have been considered self-enforcing. This notion seems to originate from certain developed countries, where the expenditure of enforcement resources to obtain a satisfactory compliance with these laws is small. Characteristically, this has been reported in jurisdictions with decreasing smoking prevalence and relatively long history in tobacco control such as Australia, ${ }^{1}$ Canada, ${ }^{2}$ England, ${ }^{3} \mathrm{New}$ Zealand $^{45}$ or at subnational levels in the USA. ${ }^{67}$ Since the entry into force of the WHO Framework Convention on Tobacco Control (FCTC), ${ }^{8}$ a much more diverse range of countries regarding socioeconomic development, legislative traditions and with different tobacco control experience and trajectories have adopted a national comprehensive smoking ban law. The evidence indicates that such a comprehensive law may face some enforcement challenges resulting in a suboptimal compliance in particular venues of some countries. For this paper, a national comprehensive smoking ban covers all indoor workplaces, indoor public places and public transport, in line with the obligations of the WHO FCTC.

A review of the WHO International Agency for Research on Cancer, considering legal smoking restrictions of different strengths, already alerted that compliance, although frequently satisfactory in most countries, was inadequate in some settings of some countries. ${ }^{9}$ In fact, based on WHO data, ${ }^{10}$ about two-thirds of the countries that had adopted national comprehensive smoke-free laws by 2014 and collected information about compliance report high or very high levels of compliance across all sectors.

A limited number of studies confirm compliance problems in some countries with national comprehensive smoke-free laws. Six years after the adoption of a national comprehensive smoke-free law in Turkey, the compliance was found to be very high in indoor offices, schools and other indoor places. Nonetheless, when assessed in coffee houses and the dining areas of government buildings and hospitals, compliance was found poor and very poor in bars and nightclubs. ${ }^{11}$ Despite a similarly comprehensive law in Albania, the exposure to second-hand smoke remained high in private workplaces, restaurants and cafes/bars/nightclubs 3 years after introduction. ${ }^{12}$ Four years after the adoption of a comprehensive national law in Greece, the great majority of its citizens reported smoking in drinking and eating public places. ${ }^{13}$ In Guatemala, compliance remained very high in the first 5 years after the introduction of their comprehensive national law. However, a study showed signs of reducing compliance in the hospitality sector. $^{14}$

Compliance with national comprehensive smokefree laws is, therefore, substantial in most countries but not in all. This study explores the correlates of high compliance in countries considered by WHO to have national comprehensive smoke-free laws in 2014.

\section{METHODS \\ Design}

This study represents an analysis of WHO cross-sectional data from 41 of the 49 countries that had a national comprehensive smoke-free law in 2014, including 40 states and 1 territory. Table 1 describes these countries. All the states included in the analysis are members of the WHO and all, except Argentina, are parties to the WHO FCTC. Explanatory and outcome variables characterising each unit of analysis circa 2014 
Table 1 Characteristics of countries included in the analysis with a national comprehensive smoke-free law in 2014

\begin{tabular}{|c|c|c|c|c|c|}
\hline \multirow[b]{2}{*}{ Country } & \multicolumn{2}{|c|}{ National comprehensive smoking ban* } & \multirow[b]{2}{*}{$\begin{array}{l}\text { Population in } \\
\text { millions (2014) } \dagger\end{array}$} & \multirow[b]{2}{*}{$\begin{array}{l}\text { Human Development } \\
\text { Index (2014)‡ }\end{array}$} & \multirow{2}{*}{$\begin{array}{l}\text { Age-standardised prevalence for } \\
\text { daily tobacco smoking, persons } \\
\text { aged } \geq 15 \text { years }(2015)(\%) \S\end{array}$} \\
\hline & $\begin{array}{l}\text { High compliance } \\
\text { (2014) }\end{array}$ & Implementation year & & & \\
\hline Albania & No & 2006 & 31.8 & 73.3 & 23.0 \\
\hline Argentina & No & 2011 & 41.8 & 83.6 & 16.3 \\
\hline Australia & Yes & 2005 & 23.6 & 93.5 & 13.4 \\
\hline Bhutan & Yes & 2010 & 0.8 & 60.5 & Not available (NA) \\
\hline Bulgaria & No & 2012 & 7.2 & 78.2 & 28.3 \\
\hline Burkina Faso & No & 2010 & 17,4 & 40.2 & 10.7 \\
\hline Canada & Yes & 2007 & 35.5 & 91.3 & 10.7 \\
\hline Chad & No & 2010 & 13.2 & 39.2 & NA \\
\hline Chile & Yes & 2013 & 17.8 & 83.2 & 26.3 \\
\hline Honduras & No & 2010 & 8.3 & 60.6 & $11.1(2013)$ \\
\hline Iran, Islamic Republic & No & 2007 & 78.5 & 76.6 & 10.0 \\
\hline Ireland & Yes & 2004 & 4.7 & 91.6 & 19.3 \\
\hline Jamaica & No & 2013 & 2.8 & 71.9 & 11.9 \\
\hline Lebanon & Yes & 2011 & 5.0 & 76.9 & 25.1 \\
\hline Libyan Arab Jamahiriya & No & 2009 & 6.3 & 72.4 & NA \\
\hline Malta & No & 2010 & 0.4 & 83.9 & 20.4 \\
\hline Marshall Islands & No & 2006 & 0.05 & NA & NA \\
\hline Mongolia & Yes & 2012 & 2.9 & 72.7 & 22.2 \\
\hline Namibia & No & 2010 & 2.3 & 62.8 & 17.2 \\
\hline Seychelles & Yes & 2009 & 0.09 & 77.2 & 16.6 \\
\hline Spain & Yes & 2010 & 47.1 & 87.6 & 25.1 \\
\hline Suriname & No & 2013 & 0.5 & 71.4 & 18.2 \\
\hline Thailand & No & 2010 & 67.2 & 72.6 & 16.9 \\
\hline Trinidad \& Tobago & Yes & 2009 & 1.3 & 77.2 & NA \\
\hline Turkmenistan & Yes & 2000 & 5.3 & 68.8 & NA \\
\hline UK & Yes & 2006 & 63.5 & 90.7 & 18.0 \\
\hline Venezuela & Yes & 2011 & 30.9 & 76.2 & NA \\
\hline West Bank \& Gaza Strip & No & 2011 & 4.4 & 67.7 & NA \\
\hline
\end{tabular}

were obtained from several survey sources described in the next section.

\section{Variables and data sources}

\section{Outcome variable}

\section{Compliance with smoke-free laws}

We obtained compliance with the national comprehensive smokefree law for 2014 from the WHO global report on the global tobacco epidemic. ${ }^{10}$ Compliance was assessed independently by five national key informants, as described in appendix 1 of the WHO report. Each key informant characterised the overall compliance with the national law as 'minimal', 'moderate' or 'high' depending on whether he or she perceived that unlawful smoking in indoor places covered under the ban in the whole territory was frequent, occasional or very rare in 2014. WHO calculated a country score by assigning to each informant's assessment two points when they deemed to have a high compliance with the law, one point when they considered a moderate compliance and no points if compliance was minimal. The scores from the five individual assessments were added to compose the country's score. The resulting score has a potential minimum of 0 and a maximum of 10 points. In the 
WHO report ${ }^{10}$ the country compliance is considered high when the country score is eight or above. In our analysis we used the same criterion, with approximately half of the observations having a score of less than eight. Compliance information was available for 47 of the 49 countries that had a national comprehensive smoke-free law.

\section{Explanatory variables}

\section{Country enforcement, socioeconomic and demographic characteristics}

- Enforcement characteristics: the following variables were considered and obtained by WHO through a separate survey of governments responded by officials at the Ministry of Health in 2015. Of the 49 countries that had a national comprehensive smoke-free law, 43 countries responded.

- legal enforcement requirements of establishment owners or managers under the smoke-free law in 2014, such as posting no smoking signs, removing ashtrays, supervising the observance of the law in their business, discouraging smoking in their establishment and notifying authorities when smokers resisted stopping the unlawful use of tobacco;

- legal penalties applicable in 2014 to law violators, such as monetary fines, administrative sanctions and criminal penalties for establishment owners/managers or monetary fines and criminal penalties for individual smokers;

- enforcement infrastructure and resources in 2014, such as whether a written inspection protocol exists, the involvement of jurisdictional levels in enforcement through training of agents and direction of inspections or the types of authorised enforcement agents and their roles;

- enforcement strategy used such as whether they had a specific initial enforcement strategy during the entry into force period, a communication strategy for compliance or a public complaint mechanism, such as a toll-free phone line;

- time elapsed since entry into force of the comprehensive national ban.

- To measure the overall enforcement practice, a variable was created adding all policy elements considered essential for an effective enforcement according to the scoring system in table 2 . The value of the variable potentially ranges from 0 if a country had none of the policy elements to 31 if it had all of them. It assumes that all variables weight the same. For the analysis, we categorised the variable into two groups depending on whether the score was equal or greater than 16 , which includes the top tercile of countries, or lower than 16 .

- Country socioeconomic, demographic and other characteristics for 2014 include the population size obtained from United Nations, ${ }^{15}$ the country's human development index from the United Nations Development Programme ${ }^{16}$ and the country's income level according to the World Bank. ${ }^{17}$ We also included the World Bank's governance indicator on the level of corruption control. ${ }^{18}$ It captures the perceptions of the extent to which public power, including law enforcement, is exercised for private gain, including both petty and grand forms of corruption, as well as hijacking control of the state by elites and private interests, including that of the tobacco industry. It gives the country's score on the aggregate indicator, in units of a standard normal distribution, that is, ranging from approximately -2.5 to 2.5 . $^{19} 20$ Finally, the national prevalence of smoking both current and daily was included as estimated by WHO. ${ }^{21}$ Smoking prevalence was considered a covariate since compliance might be related to the extent to which smoking is occurring under the hypothesis that the higher the prevalence, the more difficult enforcement might be.

\section{Data analysis}

Analyses were conducted using STATA V.13.1. ${ }^{22}$ The Fisher's exact test was used for the initial bivariate analysis to determine the significance of each potentially relevant explanatory variable of high compliance. Given the small number of observations, we calculated ORs for statistically significant variables in the initial bivariate analysis that generated less than $7 \%$ missing values $(n \geq 40)$ and no empty cells. ORs for models with more than one covariate were estimated using variables with statistically significant ORs in the bivariate analysis that generated less than $15 \%$ missing values $(n \geq 37)$ and with no more than one empty cell.

Differences in compliance were tested using the exact logistic regression, which has been suggested to analyse binary data with covariates for data sets like ours with a small number of observations or unbalanced structure ${ }^{2324}$ instead of the logistic regression that overestimates ORs in studies with a small to a moderate number of observations or sample sizes. ${ }^{25}$

Table 2 Enforcement policy elements according to a scoring system of summary enforcement practice variable

\begin{tabular}{|c|c|}
\hline Policy element & Score \\
\hline \multicolumn{2}{|l|}{ The law mandates establishment owners/managers } \\
\hline to post no smoking signs & Yes $=1$ \\
\hline to remove ashtrays & Yes $=1$ \\
\hline $\begin{array}{l}\text { to supervise the observance of the law in their } \\
\text { establishment }\end{array}$ & Yes $=1$ \\
\hline to discourage smoking in their establishment & Yes $=1$ \\
\hline $\begin{array}{l}\text { to notify the authority when resistance from smokers to } \\
\text { stop smoking }\end{array}$ & Yes $=1$ \\
\hline \multicolumn{2}{|l|}{ The law authorises sanctions for violators } \\
\hline Monetary fines for establishment owners/managers & Yes $=1$ \\
\hline Monetary fines to individual smokers & Yes $=1$ \\
\hline $\begin{array}{l}\text { Administrative sanctions to establishment owners/ } \\
\text { managers }\end{array}$ & Yes $=1$ \\
\hline Criminal penalties to establishment owners/managers & Yes $=1$ \\
\hline Criminal penalties to individual smokers & Yes $=1$ \\
\hline The country has a written inspection protocol & Yes $=1$ \\
\hline The country has a toll-free complaint line & Yes $=1$ \\
\hline Jurisdictional levels involved in training of inspectors & $\begin{array}{l}0=\text { None } \\
1=\text { only national } \\
2=\text { only subnational } \\
3=\text { both }\end{array}$ \\
\hline Jurisdictional levels involved in directing inspectors & $\begin{array}{l}0=\text { None } \\
1=\text { only national } \\
2=\text { only subnational } \\
3=\text { both }\end{array}$ \\
\hline $\begin{array}{l}\text { Number of types of agents* allowed to inspect premises } \\
\text { by surprise }\end{array}$ & $0-5$ \\
\hline $\begin{array}{l}\text { Number of types of agents* allowed to sanction violators } \\
\text { on the spot }\end{array}$ & $0-5$ \\
\hline $\begin{array}{l}\text { Country implemented a communication campaign during } \\
\text { entry into force period }\end{array}$ & Yes $=1$ \\
\hline $\begin{array}{l}\text { Country implemented regular communication campaigns } \\
\text { during and beyond the entry into force period }\end{array}$ & Yes $=1$ \\
\hline Country acted visibly against prominent violators & Yes $=1$ \\
\hline
\end{tabular}

Peruga A, et al. Tob Control 2018;27:608-613. doi:10.1136/tobaccocontrol-2017-053920 
Table 3 Correlates of overall high compliance with the national comprehensive smoke-free law. Unadjusted and adjusted ORs and 95\% Cls

\begin{tabular}{|c|c|c|c|c|c|c|c|c|}
\hline \multirow[b]{2}{*}{ Variable } & \multicolumn{4}{|c|}{ Unadjusted } & \multicolumn{4}{|c|}{ Adjusted* } \\
\hline & $\mathrm{OR}$ & $p$ & $95 \% \mathrm{Cl}$ & $\mathbf{n}$ & OR & $p$ & $95 \% \mathrm{Cl}$ & $\mathrm{n}$ \\
\hline $\begin{array}{l}\text { Countries with an increase of one point in the enforcement summary score } \\
\text { versus countries with no increase }\end{array}$ & 1.3 & $\leq 0.01$ & 1.1 to 1.6 & 41 & & & & \\
\hline $\begin{array}{l}\text { Countries where perception of corruption control efforts rank in the top quartile } \\
\text { versus countries ranking below the top quartile }\end{array}$ & 3.6 & 0.09 & 0.8 to 18.3 & 41 & 10.3 & $\leq 0.01$ & 1.7 to 117.7 & 40 \\
\hline $\begin{array}{l}\text { Countries where local jurisdictions are involved in providing training and/or } \\
\text { guidance for inspections versus countries where they are not involved }\end{array}$ & 6.4 & 0.01 & 1.4 to 34.9 & 40 & 7.2 & 0.03 & 1.1 to 85.8 & 40 \\
\hline
\end{tabular}

${ }^{*}$ Adjusted for all variables in the model.

Differences in compliance were tested for the observance of the law in all sectors jointly. Differences in compliance were also tested for the observance of the law in the hospitality sector because most national compliance studies reported above point to this sector as more recalcitrant than others. Although the statistically significant covariates of compliance in the hospitality sector were identical to those of compliance in all the sectors jointly, we do not report them because missing values in the bivariate analysis ranged $12 \%-14 \%$ depending on the explanatory variable.

\section{RESULTS}

\section{Survey response}

All 47 countries with a national comprehensive smoke-free law in 2014 and with data on compliance level with the law were requested to respond to the questionnaire exploring the elements of their compliance. Six of them did not respond: Greece, Madagascar, Russia, Saudi Arabia, Turkey and Uruguay. We compared countries responding to the survey to those not responding in relation to a series of variables available for all 47 countries. These variables were: their reported compliance level; some characteristics of their smoke-free enforcement legislation (whether the law mandates fines for violating smokers and establishments or response to complaints); the assignment of funds for enforcement; whether they have a specific agency for tobacco control and, if so, the number of Full Time Equivalents working; and some governance indices produced by the World Bank. The 41 responding countries were no different from the six non-responding countries concerning all these variables.

\section{Univariate analysis}

Table 3 indicates that the odds of high compliance with the national comprehensive smoke-free law increased by $30 \%$ with each approved policy element for the enforcement of the law of the 31 described in table 2 . In addition, the involvement of the local jurisdictions in providing either training or guidance for inspections or both was also associated with high compliance. Interestingly, the association of a high perception of corruption control efforts in the country (ranking in the top quartile of all analysed countries) with high compliance was marginally statistically insignificant. The level of compliance with the law was not associated with any economic, demographic, smoking prevalence variable or time elapsed since the implementation of the comprehensive national ban.

\section{Multivariate analysis}

Table 3 indicates that high compliance with the national comprehensive smoke-free law was associated with the involvement of the local jurisdictions in providing either training or guidance or both for inspections and a high perception of corruption control efforts in the country.

\section{DISCUSSION}

The results show that two factors seem to affect reaching a high compliance with a national comprehensive smoke-free law. First, the depth of the enforcement infrastructure and effort represented by the degree to which the local government is involved in training enforcement officials/agents or directing their inspections. This may be a sign that enforcing a comprehensive national smoke-free law requires knowledge of local premises, as well as of the idiosyncrasy of the establishment owners, smokers and communities that have to abide by the law. Therefore, the involvement of government at local level, close to the ground, provides better enforcement access to and opportunities for mobilising the support of the community for which compliance is sought. The results show that this association is independent of the size of the country, which was thought to be a possible factor determining the depth and breadth of local administrations and, therefore, of its capacity to enforce smoke-free laws. The engagement of the local government in increasing the effectiveness of the overall implementation of the law seems consistent with the reports from municipal case studies ${ }^{26-34}$ and the experience in other areas of law enforcement. ${ }^{35} 36$

Local engagement in enforcement might not be the only policy element that is associated with high compliance given that its odds increased with each policy element approved for the enforcement of the law. However, we do not know if this is because accruing policy elements has an additive effect or because the more elements approved, the more likely it is that the right ones are adopted. Therefore, government agencies may be better off concentrating on engaging the local government's level in enforcement than adding policy elements without knowing which ones are more influential than others. Furthermore, this study cannot determine if local government involvement in enforcing comprehensive smoke-free laws can happen independently of a more general or pre-existing involvement of this level of government in law enforcement or public health activities.

Second, the results show that the enforcement efforts need be conducted in both the letter and the spirit of the law, in an honest and accountable manner. The results show that when the power of enforcement is perceived to be used in the public's interest and not for private gain, even defying vested interests including those of the tobacco industry, the likelihood of high compliance with the law surges. It is well-known that, when the tobacco industry and its allies fail to prevent the adoption of a strong smoke-free law, they move onto employing tactics for derailing its implementation and undermining its enforcement. ${ }^{37} 38$ For example, 
in the Netherlands, compliance with the law was very low due to the efforts of the tobacco industry through third parties, ${ }^{39}$ and in Nigeria, the industry tried to mislead law enforcement officers on the scope of enforcement efforts. ${ }^{40}$ The fact that the results show the importance of maintaining an enforcement environment free of misconduct and misrepresentation speaks by itself of the importance of preventing swaying the implementation of the law towards industry's vested interests.

We are aware of only one study by Perkins and Neumayer that has examined determinants of compliance with adopted smokefree laws using some of the same data sources. Contrary to our findings, it showed that wealthier countries and those with lower smoking prevalence comply better with smoking bans. The study also found that countries that had a lower compliance had a higher national tobacco leaf production, which may be a proxy to the influence of tobacco interests in the country. However, this study has an important difference with ours that may make the results difficult to compare.

Perkins and Neumayer ${ }^{41}$ examine the compliance with a smoke-free law in all countries, independently of the type of law they have, be it comprehensive, or limited in scope, banning smoking completely but in only one or a few sectors, or restricting smoking to designated indoor smoking areas. Comparing the level of compliance across countries with different strengths and comprehensiveness of the smoke-free laws is problematic. The impact of partial restrictions is different than that of comprehensive bans as an unpublished analysis of the country data from the WHO global tobacco epidemic report from 2015 shows. In this analysis, high compliance with a smoke-free law is four times more likely to happen $(\mathrm{OR}=4.1,95 \%$ CI 1.7 to 9.8$)$ in countries with comprehensive national laws than in countries with weaker laws, even when adjusted for human development. ${ }^{42}$

The results of our study should be considered with caution due to several limitations. First, the cross-sectional nature of the data prevents establishing the directionality of the associations. Second, there are measurement issues. WHO obtained data on compliance with the law through a limited number of key informants that entail subjective judgement. The advantages and limitations of key informant interviews are well known. ${ }^{43}$ Perkins and Neumayer raised the issue of whether the specific compliance variable we use accurately captures the underlying reality of compliance in the country. They determined that, although there is no conclusive proof of validity, their analysis of this matter suggested some validity. The World Bank governance indicators, including on perception of corruption, have been too criticised, ${ }^{44}$ and specifically, several biases have been attributed to the indicator measuring corruption and efforts to prevent it. ${ }^{45}$ However, although no measurement is exempt from reproaches, the authors of the indicators have addressed the alleged problems reasonably. ${ }^{46}$ Third, although we analysed the existing data universe rather than a sample of countries with a national comprehensive smoke-free law, the resulting dataset contains a small number of observations, and its structure is unbalanced. In spite of taking the necessary measures to minimise the impact of these weaknesses on the analysis, the size of ORs and its CIs might indicate a bias of the association away from the null.

In conclusion, with all necessary caveats, the findings of the study point towards the importance of local involvement in enforcement, in parallel with proactively protecting the integrity of the enforcement process, counteracting misuse in favour of private and vested interests, including those of the tobacco industry and its allies. The results also point out to the need to invest minimal but essential enforcement efforts and resources despite the fact that these laws are often self-enforcing in many but not all circumstances. WHO has estimated that the adoption and enforcement of a national comprehensive smoke-free law may have a per capita cost of US\$1.6 in $2011 .^{47}$

\section{What this paper adds}

- This study provides data on the under-researched area of compliance with national comprehensive smoke-free laws across a variety of countries.

- This study shows the importance of local involvement and the integrity of the enforcement process, including counteracting the tobacco industry's vested interests to undermine the enforcement process.

- This study points out to the need to invest minimal but essential enforcement efforts and resources despite the fact that these laws are generally self-enforcing in many but not all countries and types of indoor places.

Acknowledgements We thank Ofelia Cazacu for her contribution to data collection.

Contributors AP and LSH contributed to the designing of the study. LSH was responsible for collecting the data. AP performed the data analyses. AP, LSH, XA and VP took part in the drafting of the manuscript. All the authors participated in the revising of the manuscript critically for important intellectual content and gave final approval of the version to be published. AP is the guarantor.

Funding WHO funded this study.

Disclaimer The authors alone are responsible for the views expressed in this article, and they do not necessarily represent the views, decisions or policies of the institutions with which they are affiliated.

Competing interests None declared.

Provenance and peer review Not commissioned; externally peer reviewed.

Data sharing statement All available data can be obtained by contacting the corresponding author.

\section{REFERENCES}

1 Riseley K. Report on smoke-free policies in Australia. 1st edn. Geneva, Switzerland: World Health Organization. http://www.who.int/tobacco/training/success_stories/en/ best_practices_australia_smokefree_policies.pdf (accessed 22 Aug 2017).

2 Ontario Campaign for Action on Tobacco. Municipal bylaws: ENFORCEMENT. Ocat. org. http://www.ocat.org/onlegislation/enforcement.html (accessed 22 Aug 2017).

3 Department of Health. Smokefree England - one year on. 1st edn. London, UK, 2008. http://www.smokefreeengland.co.uk/files/dhs01_01-one-year-on-report-final.pdf. (accessed 22 Aug 2017).

4 Price L, Allen M. Going smokefree in New Zealand: lessons from the battlefield. 1st edn. Auckland, New Zealand: Action on Smoking and Health, 2006. http://www. ash.org.nz/wp-content/uploads/2013/01/Research_commisoned_by_ASH/Going_ Smokefree_in_New_Zealand_lessons_from_the_battlefield.pdf (accessed 22 Aug 2017).

5 Edwards R, Thomson G, Wilson N, et al. After the smoke has cleared: evaluation of the impact of a new national smoke-free law in New Zealand. Tob Control 2008;17:e2.

6 Americans for Nonsmokers' Rights. Implementation. No-smoke.org. http://www.nosmoke.org/learnmore.php?id=113 (accessed 22 Aug 2017).

7 US Surgeon General. Reducing the health consequences of smoking: 25 years of progress. 1st edn. Rockville, Md: U.S. Dept of Health and Human Services, Public Health Service, Centers for Disease Control, Center for Chronic Disease Prevention and Health Promotion, Office on Smoking and Health, 1989.

8 Uang R, Hiilamo H, Glantz SA. Accelerated adoption of smoke-free laws after ratification of the World Health Organization framework convention on tobacco control. Am J Public Health 2016;106:166-71.

9 IARC. Evaluating the effectiveness of smoke-free policies. 13. 1st edn. Lyon, France: Handbooks of Cancer Prevention, Tobacco Control, 2009.

10 WHO. Report on the global tobacco epidemic. 1st edn. Geneva: World Health Organization, 2015.

11 Navas-Acien A, Çarkoğlu A, Ergör G, et al. Compliance with smoke-free legislation within public buildings: a cross-sectional study in Turkey. Bull World Health Organ 2016:94:92-102.

12 Zaloshnja E, Ross H, Levy DT. The impact of tobacco control policies in Albania. Tob Control 2010;19:463-8. 
13 European Commission, Directorate-General for Health and Food Safety Special eurobarometer 429: attitudes of europeans towards tobacco and electronic cigarettes. 1st edn. Brussels, Belgium: European Commission, 2015. http://ec.europa.eu/public opinion/archives/ebs/ebs_429_en.pdf (accessed 22 Aug 2017).

14 Barnoya J, Monzon JC, Briz P, et al. Compliance to the smoke-free law in Guatemala 5-years after implementation. BMC Public Health 2016;16:318.

15 UNDP. World Population Prospects: Total population - both sexes. De facto population in a country, area or region as of 1 July of the year indicated. UN - Population Division, 2016 https://esa.un.org/unpd/wpp/Download/Standard/Population/.

16 UNDP. Human development data (1980-2015) | human development reports. Hdr. undp.org, 2016 http://hdr.undp.org/en/data.

17 World Bank. World Bank Country and lending groups - World Bank data help desk.. Datahelpdesk.worldbank.org, 2017 https://datahelpdesk.worldbank.org/ knowledgebase/articles/906519-world-bank-country-and-lending-groups (accessed 22 Aug 2017).

18 Kaufmann D, Kraay A. The Worldwide Governance Indicators: Govindicators.org, 2017. http://www.govindicators.org. (accessed 22 Aug 2017).

19 Mastruzzi M, Kaufmann D, Kraay A. The worldwide governance indicators: methodology and analytical issues: Documents. worldbank.org, 2010. http:// documents.worldbank.org/curated/en/630421468336563314/The-worldwidegovernance-indicators-methodology-and-analytical-issues (accessed 22 Aug 2017).

20 Kaufmann D, Kraay A, Mastruzzi M. The Worldwide Governance indicators: methodology and analytical issues. Hague Journal on the Rule of Law 2011;3:220-46.

21 WHO. Global report on trends in prevalence of tobacco smoking. 1st edn. Geneva: World Health Organization, 2015.

22 StataCorp. Stata statistical software: release 13. College Station, TX: StataCorp LP, 2013.

23 Mehta CR, Patel NR. Exact logistic regression: theory and examples. Stat Med 1995; 14:2143-60.

24 Yoneoka D, Saito E. A statistical note on analyzing and interpreting individual-level epidemiological data. J Epidemiol 2015;25:337-8.

25 Nemes S, Jonasson JM, Genell A, et al. Bias in odds ratios by logistic regression modelling and sample size. BMC Med Res Methodol 2009;9:56.

26 Arul R, Angelis S, Ali S, et al. WHO smoke-free city case study: towards breathing clean air in Chennai - a smoke-free city case study: WHO centre for health development, 2011. http://www.who.int/kobe_centre/interventions/smoke_free/chennai_web_final. pdf?ua=1 (accessed 22 Aug 2017)

27 Dawson J. WHO smoke-free city case study: from city to national legislation: a case study of Liverpool's smoke-free intervention: WHO centre for health development, 2011. http://www.who.int/kobe_centre/interventions/smoke_free/liverpool_web_ final.pdf?ua=1 (accessed 22 Aug 2017).

28 Ebrard Casaubón M, Ahued-Ortega A, Robles-García R, et al. WHO smoke-free city case study: towards $100 \%$ smoke-free environment: the case study of Mexico City, Mexico:WHO centre for health development, 2011. http://www.who.int/kobe_ centre/interventions/smoke_free/mexico_city_web_final.pdf?ua=1. (accessed 22 Aug 2017).

29 Goswami H. WHO smoke-free city case study: experience of Chandigarh as a smokefree city: WHO centre for health development, 2011. http://www.who.int/kobe centre/interventions/smoke_free/chandigarh_web_final.pdf?ua=1 (accessed 22 Aug 2017).

30 Guedes-Campelo D. WHO smoke-free city case study: recife breathing better, case study of smoke-free policy: WHO Centre for Health Development, 2011. http://www. who.int/kobe_centre/interventions/smoke_free/recife_web_final.pdf?ua=1. (accessed 22 Aug 2017).

31 Mohamed M, Shams A. WHO smoke-free city case study: tobacco-free cities for smoke-free air: a case study in Mecca and Medina: WHO centre for health development, 2011. http://www.who.int/kobe_centre/interventions/smoke_free/ mecca medina web final.pdf?ua=1 (accessed 22 Aug 2017).

32 Odhiambo F, Mutai J, Endau W, et al. WHO smoke-free city case study: Smoke-free Nakuru - the first east African city implementing subnational smoke-free policy: WHO centre for health development, 2011. http://www.who.int/kobe_centre/interventions/ smoke_free/nakuru_web_final.pdf?ua=1 (accessed 22 Aug 2017).

33 Sadykova J. WHO smoke-free city case study: Almaty - the first smoke-free city in the post-Soviet region: WHO centre for health development, 2011. http://www.who.int/ kobe_centre/interventions/smoke_free/kazakhstan_web_final.pdf?ua=1 (accessed 22 Aug 2017).

34 Villarreiz D. WHO smoke-free city case study: advancing the enforcement of the smoking ban in public places - Davao City, Philippines: WHO centre for health development, 2011. http://www.who.int//kobe_centre/interventions/smoke_free/ davao_city_web_final.pdf?ua=1 (accessed 22 Aug 2017).

35 van Caem B, van Steden R, Boutellier H, et al. Community policing 'Light': on proximity and distance in the relationship between neighbourhood coordinators and citizens. Policing 2013;7:263-72.

36 Lawrence S, McCarthy B. What works in community policing? a best practices context for measure $Y$ efforts: The Chief Justice Earl Warren Institute on Law and Social Policy, 2013. https://www.law.berkeley.edu/files/What_Works_in_Community_Policing.pdf (accessed 22 Aug 2017).

37 Hyland A, Barnoya J, Corral JE. Smoke-free air policies: past, present and future. Tob Control 2012;21:154-61.

38 Tobacco industry interference: a global brief: Tobacco Free Initiative Publications, 2012. http://apps.who.int/iris/bitstream/10665/70894/1/WHO_NMH_TFI_12.1_eng. pdf (accessed 22 Aug 2017).

39 Gonzalez M, Glantz SA. Failure of policy regarding smoke-free bars in the Netherlands. Eur J Public Health 2013;23:139-45.

40 Ezeamalu B. Nigeria: group accuses British American Tobacco of misleading police on tobacco law: Premium Times of Nigeria, 2014. http://www. premiumtimesng.com/ news/166912-group-accuses-british-american-tobacco-of-misleading-police-ontobacco-law.html (accessed 22 Aug 2017).

41 Perkins R, Neumayer E. Adoption and compliance in second-hand smoking bans: a global econometric analysis. Int J Public Health 2014;59:859-66.

42 Schotte K. GTCR analysis: compliance 2014 by level of Smoke-Free law achievement, 2017.

43 Kumar K. Conducting key informant interviews in developing countries: US Agency for International Development, 1989. http://pdf.usaid.gov/pdf_docs/pnaax226.pdf (accessed 22 Aug 2017).

44 Arndt C, Oman C. Uses and abuses of governance indicators. 1st edn. Paris: Development Centre of the Organisation for Economic Co-operation and Development, 2006.

45 Knack S. Measuring corruption in Eastern Europe and Central Asia: a critique of the cross-country indicators. Washington, DC: World Bank, 2006. https://core.ac.uk/ download/pdf/6522082.pdf (accessed 22 Aug 2017).

46 Kaufmann D, Kraay A, Mastruzzi M. The Worldwide Governance indicators project: answering the critics. Washington, DC: World Bank, 2007. https://openknowledge. worldbank.org/handle/10986/7203 (accessed 22 Aug 2017).

47 Chisholm D, Abegunde D, Mendis S. Scaling up action against noncommunicable diseases. 1st edn. Geneva, Switzerland: World Health Organization, 2011. 